\title{
녹내장과 갑상샘눈병증
}

\section{Glaucoma and Thyroid Eye Disease}

\author{
박 정 열 \\ Jung Yul Park
}

부산대학교 의과대학 안과학교실

Department of Ophthalmology, Pusan National University School of Medicine, Busan, Korea

갑상샘눈병증(thyroid eye disease, TED)과 녹내장(glaucoma) 은 두 질환 모두 만성적인 경과를 보이며, 잘 조절되지 않는 경우 삶의 질에 지대한 영향을 끼칠 수 있다. TED은 자가면역에 의한 세포매개 면역기능의 변화로 인해 외안근 및 안와 결체조직의 진 행성 염증을 일으키는 질환 ${ }^{1}$ 으로 1) 안구 뒤 조직의 염증물질 침 착, 2) 외안근과 외안근 주변의 결합조직, 그 사이공간을 채우는 결합조직내 지방조직의 팽창, 3) 글리코스아미노글리칸(glycosaminoglycan, GAG)의 과다한 생성으로 인한 외안근, 안와지방 과 안와결합조직의 팽창을 주요 병인으로 한다. ${ }^{2}$

$\mathrm{TED}$ 과 녹내장에 관한 연관성에 대해 정확히 밝혀진 것은 없으 나, TED에서 안압이 높아지는 원인에 대해서는 몇 가지 이론들 이 제기되고 있다: 1) 안와의 염증과 울혈(congestion)로 인한 상 공막혈관압(episcleral venous pressure, EVP)의 증가, 2) 섬유주 내의 뮤코다당체(Mucopolysaccharide) 침착과 이로 인한 저항의 증가, 3) 녹내장과 갑상샘 질환의 유전적 연관성, 4) 외안근의 비 대와 섬유화로 인한 안구의 압박이 대표적이다. ${ }^{3}$ 또한, 지속적인 안구의 노출로 인한 만성 염증과 섬모체의 이동으로 인한 이차적 인 폐쇄 역시 중요한 원인으로 알려져 있다. ${ }^{4}$

안압이 높아진 환자에서 TED이 동반되었을 때, 이것이 TED과 연관되어 나타난 것인지 아니면 녹내장성 변화와 연관되어 있는 지 구분하기 어려운 경우가 많고, 치료의 방향을 결정하기가 어려 운 경우가 있다. 따라서 $\mathrm{TED}$ 와 녹내장의 연관성에 대해 알아보 는 진단과 치료에서 주의할 점을 알아보고자 한다.

\section{본론}

\section{갑상샘 이상과 녹내장}

갑상샘기능저하증(hypothyroidism)은 안압을 증가시키며, 갑 상샘기능항진증(hyperthyroidism)은 주로 안압을 낮춘다고 보 고되지만, 문헌마다 다양한 결과를 보인다. Smith et $\mathrm{al}^{5}$ 은 갑상샘 기능저하증에서 개방각녹내장(primary open angle glaucoma, $\mathrm{POAG})$ 의 유병률이 더 높다고 보고하였으며, 이것은 갑상샘기능 의 저하가 효소 활동(enzyme activity)을 감소시키고, 히알루론 산(hyaluronic acid)의 분해를 감소시키는 데 있다고 하였으며, 이 와는 반대로 Cheng and Perkins ${ }^{6}$ 은 갑상샘기능저하증과 안압의 연관성은 찾을 수 없다고 보고하기도 하였다.

한국인을 대상으로 한 최근의 연구 결과에서 저자는 $\mathrm{T} 3$ 의 수치 가 녹내장이 있는 환자에서 유의하게 높다고 보고하였으며, free $\mathrm{T} 4$ 와 T3의 수치가 증가할수록 안압이 상승하는 경향을 보인다고 보고하였다. 하지만 갑상샘항진증 및 저하증과 녹내장의 발생은 서로 연관성이 없는 것으로 보고하였다.

주목할 만한 연구는 2008년 미국인 12,376 명을 대상으로 한 갑 상샘 질환과 녹내장의 연관에 대한 보고이다. 이 보고에서 녹내장 의 유병률은 일생에 한 번이라도 갑상샘 질환이 있었던 환자들에 서 그렇지 않았던 환자들에 비해 유의하게 높게 조사되었다 $6.5 \%$ vs $4.4 \%, p=0.0003)$. 그리고 갑상샘 질환을 한 번이라도 않은 경 우 녹내장의 발생이 $38 \%$ 증가한다고 보고하였다. ${ }^{8}$

이 두 질환은 생물학적 연관성을 지니고 있는 것으로 생각되 며, 예를 들어 갑상샘기능저하증의 경우 전반적인 효소 활동(enzyme activity)의 저하로 안구 혈관에 침착물이 증가하여 방수유 출로의 저항을 증가시킨다. 이로 인해 안압이 높아지며, 녹내장의 
발생과 관련이 있다고 하였다. ${ }^{8}$

\section{갑상샘눈병증(TED)과 안압, 안압의 측정}

TED에서의 안압상승은 1918년에 처음 보고되었고, ${ }^{9}$ 안와 내 압력의 상승이 EVP의 증가를 유발하고 안압을 상승하게 한다는 사실이 알려졌다. 특히 상방주시에서 안압은 상승한다고 알려져 있는데, 이유는 하직근의 섬유화와 불충분한 이완으로 인해 상방 주시에서 안구가 압박을 받기 때문이다. Kalmann and Mourits ${ }^{10}$ 는 안와감압술은 안와내 압력을 감소시켜 안압을 낮추며, 하직근 후전술은 근육의 긴장도를 감소시키고 안구압박을 줄여 안압을 감소시킨다고 보고하였다. ${ }^{10}$

$\mathrm{TED}$ 환자에서 안압을 측정할 때는 주의가 필요하다. 하직근의 섬유화 혹은 비후가 있는 TED 환자의 경우 고개를 들고 하방주 시를 하여 앞을 보는 자세를 취한다. 이런 경우 안압을 측정하는 자세가 중요한데, 세극등현미경에 고개를 올리거나 혹은 앉은 자 세에서 눈을 정면으로 보도록 하여 안압을 측정하면, 상대적으로 상방주시가 되어 하직근이 안구를 압박하여 안압이 높게 측정된 다고 보고하였다. 따라서 Kalmann and Mourits ${ }^{10}$ 는 TED 환자들 의 안압측정시 standard position (고개를 들고 약간 하방주시를 한 상태)에서 안압을 측정하라고 보고하였다. Cockerham et al ${ }^{11}$ 이 TED 환자를 대상으로 보고한 고안압증(ocular hypertension, $\mathrm{OHT}$ )의 높은 유병률은 정면주시에 따른 안압의 상승과 연관이 있을 수 있는 것이다.

\section{갑상샘눈병증(TED)과 고안압증(OHT), 녹내장의 관계}

일반적으로 $\mathrm{TED}$ 에서 녹내장의 유병률은 높은 것으로 알려져 있으나, ${ }^{12}$ 모든 연구에서 동일한 결과를 보이는 것은 아니다. ${ }^{10}$ 이 는 TED의 다양한 임상양상과 만성적인 병의 진행 경과, 스테로이 드 약물치료 여부 등이 녹내장의 유무를 확인하는 데 영향을 주 는 것으로 생각된다.

최근 TED 환자를 대상으로 한 연구에서, Behrouzi et $\mathrm{al}^{13}$ 은 $\mathrm{POAG}$ 의 경우 일반인과 비교하여 유병률에 차이가 없으나 $\mathrm{OHT}$ 는 TED가 있는 경우 더 많은 수에서 관찰되었다고 보고하였으며, $\mathrm{OHT}$ 은 특히 활동성 갑상샘눈병증(active TED)과 관계된다고 보 고하였다.

Active TED에서 EVP의 증가는 안압의 증가로 나타나게 되어 직접적인 연관성이 설명되지만, 활동성 시기(active phase)가 지 나고 안정기의 갑상샘눈병증(chronic, inactive TED)이 되면 그 관계는 조금 더 복잡해진다. ${ }^{13}$ Active phase가 지나가고 inactive phase에도 안압이 증가된 상태로 유지되는 이유는, 이차적인 구 조의 변화에 따른 지속적인 EVP의 증가가 방수배출에 문제를 일
으키는 것으로 생각된다.

반면 de Silva et $\mathrm{al}^{14}$ 은 TED과 동반된 OHT은 3.7-3.9\%라고 보 고하였고, 녹내장과 $\mathrm{OHT}$ 모두 일반 인구와 비교하였을 때 유의 미한 차이가 없다고 하였다. 시신경과 시야검사에서 진행성 녹 내장성 변화 역시 일반 인구와 비교해 차이가 없다고 보고했다. $\mathrm{TED}$ 와 녹내장에 관한 다양한 보고들에도 불구하고 중요한 점은 $\mathrm{TED}$ 이 있는 환자에서 안압의 면밀한 측정과 녹내장 유무에 대 한 관심이 필요하다는 사실이다.

\section{갑상샘눈병증(TED)환자에서 녹내장의 치료}

$\mathrm{TED}$ 환자에서 안압상승의 중요한 요인 중 하나는 스테로이드의 사용이다. Kersey and Broadway ${ }^{15}$ 은 스테로이드의 국소 및 전신 사용이 안압을 상승시킨다 보고하였는데, 여기에는 1) GAG의 축 적과 부종에 의한 섬유주(trabecular meshwork) 폐쇄, 2) 섬유주 내피세포(trabecular meshwork endothelial cell)의 탐식작용 저 하로 인한 방수유출저하, 3) 섬유주세포(trabecular meshwork cell)의 protein myocilin, 4) 스테로이드 입자에 의한 방수유출저 하가 역할을 하는 것으로 알려져 있다.

TED 환자에서 녹내장의 치료는 모든 녹내장 환자들과 동일한 방식으로 치료를 할 수 있다. 또한 대부분의 경우에서 TED와 스 테로이드 유발 녹내장 모두 일반적인 점안 항녹내장약물치료로 효과적으로 조절할 수 있다. ${ }^{16}$

\section{갑상샘눈병증(TED)과 녹내장에서 망막신경섬유층(retinal nerve fiber layer, RNFL) 변화}

녹내장성 시신경병증의 경우 시신경유두주위 RNFL thickness 의 감소와 시신경유두함몰을 특징으로 한다. 녹내장 환자의 경우 시야나 시력의 변화 이전에 RNFL의 변화가 먼저 나타나기 때문 에, RNFL defect의 조기 발견은 중요한 의미를 가진다. ${ }^{17}$ 고안압 을 동반한 TED 환자를 대상으로 한 보고에서 환자들은 녹내장 성 시야손상이 없으며, RNFL thickness 역시 유의한 감소가 없 다고 보고하였다. RNFL thickness가 유의하게 감소한 환자들만 을 대상으로 분석한 경우 유의한 변화는 상측과 하측 사분면에 서 나타났다고 보고하였다. 압박시신경병증(compressive optic neuropathy, $\mathrm{CON}$ )으로 진행하여 RNFL defect가 일어난 경우, 이 위치는 압박의 위치와 연관하여 나타난다고 보고하였다. ${ }^{18}$

결론적으로 고안압을 동반한 TED 환자에서 RNFL thickness 의 감소는 녹내장에 의한 것인지 혹은 $\mathrm{CON}$ 에 의한 것인지에 대 한 구분은 어렵다. 하지만 RNFL thickness의 감소는 녹내장성 시신경변화가 안저검사에서 발견되기 전이나, $\mathrm{CON}$ 의 증거가 컴 퓨터단층촬영(computed tomography)상에서 발견되기 전이라도 
안압상승에 의한 RNFL 손상을 의미하며, 이것은 항녹내작약물 사용의 근거가 될 수 있다.

\section{결론}

갑상샘의 이상에 따른 안압의 상승과 녹내장의 발생에 대한 보 고로 다양한 것을 알 수 있었다. 주목해야 할 점은 TED이 안압 에 영향을 줄 수 있다는 점이다. 특히 자세의 변화나 주시의 변화 에 따른 안압의 상승에 주의하여 안압을 측정하고, 이들에 대한 녹내장 유무의 면밀한 관찰이 필요하다. 또한 RNFL thickness의 측정은 환자들의 진단과 평가에 안압의 측정과 함께 효과적인 도 구가 될 수 있다. 갑상선 이상 및 $\mathrm{TED}$ 의 병태생리와 기전에 대해 서 이해하고, 이것이 안압과 녹내장에 영향을 줄 수 있음을 인지 하여, 환자의 적절한 진단과 이해를 통해 효과적인 치료를 받을 수 있도록 유의해야겠다.

\section{References}

1. Stein JD, Childers D, Gupta S, et al. Risk factors for developing thyroid-associated ophthalmopathy among individuals with Graves disease. JAMA Ophthalmol 2015;133:290-6.

2. Kvetny J, Puhakka KB, Røhl L. Magnetic resonance imaging determination of extraocular eye muscle volume in patients with thyroid-associated ophthalmopathy and proptosis. Acta Ophthalmol Scand 2006;84:419-23.

3. Goldberg I. Thyroid eye disease and glaucoma. J Glaucoma 2003;12:494-6.

4. King JS, Netland P. Glaucoma in thyroid eye disease. In: Dutton J, Haik B, eds. Thyroid eye disease: diagnosis and treatment, 1st ed. New York: Talor and Francis Group, 2002; chap. 32.

5. Smith KD, Arthurs BP, Saheb N. An association between hypothyroidism and primary open-angle glaucoma. Ophthalmology 1993;100:1580-4.
6. Cheng H, Perkins ES. Thyroid disease and glaucoma. Br J Ophthalmol 1967;51:547-53.

7. Won YS, Kim DY, Kim JM. Glaucomatous optic nerve changes and thyroid dysfunction in an Urban South Korean Population. J Ophthalmol 2017;2017:8280209.

8. Cross JM, Girkin CA, Owsley C, McGwin G. The association between thyroid problems and glaucoma. Br J Ophthalmol 2008;92:1503-5.

9. Wessely K. Discussion of Hertel E. Ber Dtsch Ophthalmol Ges 1918;41:80-1.

10. Kalmann R, Mourits MP. Prevalence and management of elevated intraocular pressure in patients with Graves' orbitopathy. Br J Ophthalmol 1998;82:754-7.

11. Cockerham KP, Pal C, Jani B, et al. The prevalence and implications of ocular hypertension and glaucoma in thyroidassociated orbitopathy. Ophthalmology 1997;104:914-7.

12. Ohtsuka K, Nakamura Y. Open-angle glaucoma associated with Graves disease. Am J Ophthalmol 2000;129:613-7.

13. Behrouzi Z, Rabei HM, Azizi F, et al. Prevalence of openangle glaucoma, glaucoma suspect, and ocular hypertension in thyroid-related immune orbitopathy. J Glaucoma 2007;16:35862.

14. da Silva F, Rodrigues M, Akaishi P, Cruz AA. Graves' orbitopathy: frequency of ocular hypertension and glaucoma. Eye (Lond) 2009;23:957-9.

15. Kersey J, Broadway D. Corticosteroid-induced glaucoma: a review of the literature. Eye (Lond) 2006;20:407-16.

16. Scherer WJ, Hauber FA. Effect of latanoprost on intraocular pressure in steroid-induced glaucoma. J Glaucoma 2000;9:179-82.

17. Fortune B, Cull G, Reynaud J, et al. Relating retinal ganglion cell function and retinal nerve fiber layer (RNFL) retardance to progressive loss of RNFL thickness and optic nerve axons in experimental glaucoma. Invest Ophthalmol Vis Sci 2015;56:3936-44.

18. Forte R, Bonavolontà $\mathrm{P}$, Vassallo $\mathrm{P}$. Evaluation of retinal nerve fiber layer with optic nerve tracking optical coherence tomography in thyroid-associated orbitopathy. Ophthalmologica 2010;224:116-21. 